\title{
KEMATIAN BUKAN AKHIR DARI SEGALANYA
}

\author{
Agustinus Faot. ${ }^{1)}$, Jonathan Octavianus ${ }^{2)}$, Juanda ${ }^{3)}$ \\ ${ }^{1)}$ Evangelical Theological Seminary of Indonesia - Surabaya \\ E-mail: agustinus@sttii-surabaya.ac.id \\ ${ }^{2)}$ Evangelical Theological Seminary of Indonesia - Surabaya \\ E-mail: jonathanoctavianus@sttii-surabaya.ac.id \\ ${ }^{3)}$ Evangelical Theological Seminary of Indonesia - Surabaya \\ E-mail: juanda@sttii-surabaya.ac.id
}

\begin{abstract}
Death events are often regarded as an adverse event, tiring, painful because death picks up someone you love. When humans are abandoned by loved ones, be they husbands, wives, children, lawyers, friends, friends or extended family because death is certain to be miserable in sadness, so some people consider too much death as a detrimental, tiring, tense or torturous event. It is important to understand that death does not recognize wealth, profession, position, honor. Death picks up humans at a time that can't be realized. Grieving when experiencing death is not the best solution because no one gets up again from death because of sadness. Death also comes without asking for permission from humans, because death is part of life. But it is important for humans to fully understand that behind the death which is considered as a detrimental, sad, painful thing, there is a great joy awaiting the death of a spirit. This issue will be resolved in this article.
\end{abstract}

Keywords: Death, Part of Life, Understand

\section{PENDAHULUAN}

Sadar atau tak sadar, kematian merupakan suatu kepastian yang akan dialami oleh manusia. Kematian tidak mengenal kekayaan, jabatan, kondisi bahkan seringkali kematian datang secara tiba-tiba, tanpa disadari manusia ada yang pergi meninggalkan orang-orang yang dicintainya. Kematian datang tanpa diundang, atau tidak dapat disogok dengan kekayaan yang manusia miliki.

Sekuat apa pun manusia ia tidak akan pernah dapat menghindar dari kematian, sebab kematian merupakan bagian dari kehidupan. Kematian juga merupakan satu-satunya jembatan untuk manusia berpindah tempat dari yang fisik ke alam roh yang tidak kelihatan.

Sedih ketika ditinggalkan oleh kekasih menjadi wajar bagi semua manusia. Hilang harapan karena ditinggalkan suami atau istri yang menjadi kekuatan dalam rumah tanggal, putus asa karena ditinggalkan orang yang dicintai, semuanyanya menjadi wajar bagi manusia. Namun sering manusia tidak pernah memikirkan tentang kehidupannya di balik kematian orang yang dianggap yang kuat, yang dapat diharapkan, yang dicintai bahkan diandalkan dalam hidupnya. Untuk menjawab pertanyaan ini harus membaca semua teori tentang kehidupan di balik kematian.

Dalam Perjanjian Baru mengajarkan bahwa orang-orang yang telah mati akan dibangkitkan pada waktu kedatangan Kristus kedua kali. Ketika mendengar akan ungkapan ini pasti muncul pertanyaan! Di mana mereka yang telah meninggal selama kurung waktu antara kematian mereka dan kedatangan Tuhan Yesus yang kedua kali? Atau dengan kata lain di mana mereka menunggu selama kurun waktu tersebut.

Wajar untuk berpikir bahwa mereka berada di suatu tempat di dalam priode antara kematian mereka dan kedatangan yang kedua kali, untuk membangkitkan mereka. Calvin berpendapat bahwa bagi orang-orang percaya masa antara adalah masa sukacita dan pengharapan atau dengan kata lain, masa di dalam sukacita itu, belum sepenuhnya dan belum sempurna. ${ }^{1}$

Jadi konsepsi ini secara keseluruhan menyatakan keadaan orang-orang mati dalam masa antara kematian mereka dan kedatangan Tuhan

1. Calvin Tracts and treatises of The Reformend faith, terjemah. H. Beveridge (Grand Rapids: Eerdmand, 1958),III. 413-490 
Yesus Kristus yang kedua kali. Bahwa sekalipun mereka menunggu dalam kurung waktu 'sementara' untuk peghakiman tetapi mereka sedang menunggu di dalam suatu kondisi tertentu, jika dicermati kalimat ini kondisi yang dialami bisa berbicara soal kebagain atau penderitaan, oleh sebab itu harus diselidiki yang lebih pasti menurut Akitab kita yakini sebagai pembuktian kebenaran yang murni mutlak dengan utuh dalam menyatakan suatu kebenaran.

Sehubungan dengan ini Millar J. Erickson mengatakan ada dua alasan mengapa banyak orang kristen tidak mampu secara efektif melayani orang yang sedang berkabung. Yang pertama, karena secara relatif Alkitab tidak berbicara banyak tentang doktrin "intermediate state"' alasan kedua adanya kontroversi teologis yang berkembang. ${ }^{2}$

Menurut Millar J. Erikson, perbedaan pemahaman tentang dunia orang itu terjadi karena secara relatif Alkitab tidak banyak memaparkan doktrin tentag "intermediate State" atau di kenal dengan "masa antara" dan perbedaan itu ada karena perbedaan pemahaman teologis. Jadi dalam kutipan tersebut dapat membuka pengertian penulis bahwa perbedaan pemahaman itu terjadi karena cara pandang teologia yang tidak sama.

Oleh karena itu, untuk dapat mengarahkan umat manusia kepada pemahaman yang benar penulis akan lebih mendalami dalam ilmu eskatologi yang secara khusus berbicara tentang dunia orang mati yang diyakini oleh orang kristen dan yang tertulis dalam Alkitab. Yang secara khusus tertuju pada injil Lukas 16:19-31.

\section{Definisi Eskatologi}

Kata Eschatology berasal dari kata Yunani Eskhaton dan Logos. Kata Eskhatos berarti: last (= akhir / terakhir), utmost (= terjauh / tertinggi), extreme (= akhir / terjauh). Kata ini bisa digunakan tentang tempat, pangkat / kedudukan, waktu. Kata Logos berarti 'kata' / 'firman' atau 'ucapan' atau 'ajaran'.Eschatology = ajaran / doktrin tentang akhir jaman. ${ }^{3}$ Eskatologi adalah ilmu yang mempelajari hal-hal yang akan datang (baik yang akan datang pada waktu ditulis maupun yang akan datang bagi pembaca). ${ }^{4}$ Sedangkan dalam eskatologi Alkitabiah Studi ini merupakan penutup dari sistematikan teologi. Hal ini bukan saja merupakan klimaks, atau

\footnotetext{
${ }^{2}$ Millard J. Erickson Teologi Kristen Volum tiga (Malang, Gandum Mas. 1985), 505

${ }^{3}$ Pdt. Budi Asali, M. Div. Reformend Dogmatics (Surabaya,Golgota Ministry, 2007) hal 737/738.

${ }^{4}$ Charles C. Ryrie Dispensationalism dari Zaman ke Zaman (Malang, Gandum Mas, 1995)213
}

puncak dari studi teologi, namun merupakan suatu ketrampilan tersendiri, dan menunjukan adanya kedisiplinan ilmu yang menuntut kemampuan untuk menentukan aspek teologia secara terperinci, dan penegasan tentang penafsiran yang konsisten terhadap Alkitab dari Perjanjian Lama sampai Perjanjian Baru harus dipelihara.

Dan harus diakui bahwa studi eskatologi merupakan ilmu yang banyak menemui kerumitankerumitan yang sangat luarbiasa dalam mengamati hal-hal yang misteri dalam Alkitab, namun Tuhan telah memberi hikmat kepada manusia untuk mengamati kesulitan-kesulitan itu dengan menggunakan cara pandang Alkitab, karena ada halhal misteri yang manusia tidak boleh mengetahuinya, hanya Tuhan sendiri yang tahu, manusia perlu memperhatikan dengan teliti supaya tidak sesat. Maka dalam pengamatan studi eskatologi penulis tunduk sepenuhnya pada Alkitab sebagai sumber kebenara sesungguhnya, dan bukubuku teologia yang isinya merupakan ilmu yang bersumber dari Alkitab, bukan berpusat pada rasio. Sebab pemahaman yang berpusat pada rasio pasti tidak konsisten dalam menafsirkan Alkitab.

Dalam hal ini, dirusmuskan sebagai berikut: Prinsip Hermeneutikanya itu mendasar bagi seluruh sistem termasuk eskatologinya. ${ }^{5}$ Maka dalam memahami Alkitab harus dengan cara pendekatan yang induktif bukan dengan pendekatan deduktif karena memang cara pendekatan ini akan berpengaruh pada pengamatan dan pengamatan ini juga pasti berpengaruh pada pengajaran. Oleh sebab itu, penelitian semakin mendalam dan tunduk sepenuhnya pada konteks, memang benar bahwa perumpamaan ini bukan hanya sebatas cerita. Tetapi suatu pengajaran yang memunculkan nilai-nilai kehidupan roh setelah manusia meninggal. Tentang tujuan arwah, kondisi yang akan dialami, dan posisi keduan pribadi yang dimaksudkan dalam isi perumpamaan.

\section{Definisi Tentang Konsep Dunia Orang Mati}

Berhubungan dengan konteks perumpamaan berbicara tentang hal yang bersifat eskatologis dalam hal ini dunia orang mati. Untuk mendefenisikan konsep dunia orang mati tidak bisa melangkahi atauran kosakata dalam Kamus Besar Bahasa Indonesia. Hal ini, bertujuan supaya tidak salah dalam memaknai konsep dunia orang mati.

5. Charles C. Ryrie Dispensationalism dari Zaman ke Zaman (Malang, Gandum Mas, 1995) 216 


\section{Menurut Kamus Teologi}

Dalam Kamus Teologi dapat mengartikan Kematian sebagai akhir kehidupan jasmani, yang terjadi secara otomatis, menurut waktu yang ditetapkan oleh Tuhan, dan tidak ada satu pun manusia yang mampu menolak kematian.Dengan kematian sejarah hidup kita dihadapan Allah mencapai bentuk yang lengkap dan tak dapat diubahkan. Kitab suci memandang kematian sebagai hal yang alamai, (Mzm 49 11-12; ayat 40:6-7) dan sebagai akibat dosa (Kej.3:19; Rm 5:12). Kematian adalah musuh terakhir yang harus dikalahkan (1Kor 15:26) dengan keikutsertaan kita dalam kebangkitan Kristus. $^{6}$

Konsep dunia orang mati menurut kamus teologi kematian sesungguhnya adalah "upah dari dosa yaitu kematain kekal bukan hanya sebatas kematian fisik. namun penjelaskan kamus teologi lebih menunjuk kepada perpisahan dari Allah itulah yang dimaksud dengan kematain. Maka kematian semacam inilah yang harus dikalahkan oleh umat manusia pada umumnya, dan strategi yang dapat memampukan manusia untuk mengalahkan kematian tersebut manusia harus hidup di dalam Tuhan Yesus supaya manusia akan dibangkitakan bersama Dia, serta memberikan kemenangan atas kuasa maut.

\section{Menurut Ensiklopedi Alkitab Masa Kini}

Dalam penjelasan konsep kematian menurut Ensiklopedi dapat mendefenisikan kematian termasuk peristiwa yang paling lumrah; manusia ditetapkan untuk mati hanya satu kali saja (Ibr 9:27), tidak bisa dibantah. Dalam Ensiklopedi untuk mengartikan kematian dibagi menjadi dua bagaian yang pertama, kematian badani yaitu, badan yang diciptakan harus mengalami kematian dan kerusakan badani dan pembusukan tak dapat dielakan. Yang kedua, kemataian rohani ialah hukuman yang dijatuhkan Allah (Rm 6:23) upah dosa adalah maut, bahwa setiap pendosa patut dihukum mati (Rm $1: 32){ }^{7}$ Kematian yang terdefinisikan dalam ensiklopedi digolongkan dalam dua bagian yaitu secara badani dan secara rohani.

Namun dalam bentuk kematian badani yang akan mengalami kerusakan, dan hal ini adalah suatu keharusan. Sedang kematian secara rohani ini pasti terjadi tetapi relatif bukan suatau keharusan orang bisa mengalami kematian Rohani dan tidak, tetapi jika hal ini dialami oleh manusia dianggap sebagai suatu pemberontakan manusia terhadap Allah. Sehingga roh dan jiwa manusia terpisah dari Allah untuk selamanya. Maka sangat jelas bahwa kematian kedua itu di sebabkan oleh ketidaktaatan manusia sendiri. Setiap orang yang memberontak terhadap Allah pada akhir kehidupannya ia akan mengalami hukuman kematian, dalam arti berpisah dengan Allah untuk selamanya.

\section{Menurut Kamus Pintar Alkitab}

Dalam kamus pintar Alkitab kosep kematian dijelaskan dalam bahasa Yunani menggunakan beberapa istilah untuk bisa menjelaskan konsep kematian yang dimaksudkan oleh Alkitab secara khusus tertuju pada injil Lukas 16 : 19-31.kata "mati" ialah nekrous (akusatif, plural, maskulin) dari kata nekros (Ef 2:1,5), berarti ebnoxious to death "kematian yang buruk, menjijikan atau mortal "yang mematikan" dalam (The Analytical Greek Lexicon). Kata nekrous juga bisa berarti dead "mati" lifelles "tidak bernyawa" on a death person 'orang mati' useless 'tidak berguna, tidak bermanfaat' (A Concise Greek English Dictionary of the New Testament). ${ }^{8}$ Konsep kematian menurut kamus pintar Alkiab merupakan suatu keadaan buruk, atau menjijikan yang dialami oleh setiap manusia, dan arti lain yang dijelaskan juga kematian itu disebabkan oleh "moral" artinya moral yang tidak benar itu "yang mematian", standat untuk mengetahui benar atau tidak benarnya moral manusia terhadap dirinya dan lingkungan dimana ia berlindung, itu terukur dari norma-norma dalam undang-undang yang ditetapkan. Namun dalam konteks ini moral manusia yang tidak benar itu bukan tertuju pada manusia tetapi tertuju pada Allah sendiri, sehingga standat untuk mengukur kebenaran moral harus sesuai dengan Alkitab, sebagai Firman Allah yang satu-satunya, sungguh sangat benar untuk membuktikan kebenaran dengan seadiladilnya tidak memihak.
${ }^{6}$ Edward G. Farrugia, SJ. Kamus Teologi (Yogyakarta, Fakultas Teologi Wedabhakti Yogyakarta. 1995)137.

${ }^{7}$ J.I.Paker Ensiklopedi Alkitab Masa Kini ( Yayasan Komunikasi Bina Kasih, Jakarta 1974)35-36
${ }^{8}$ Selvester M. Tacoy, M.Div. Kamus Pintar Alkitab (Kalam Hidup Bandung, 2012). 203 


\section{Tujuan Arwah Orang Mati}

Menurutu Alkitab, ketika manusia meninggal, jiwa dan roh orang-orang yang ada didalama Yesus roh mereka akan pergi ke surga (1 Kor 5:5) dan sorga yang dimaksudkan adalah Firdaus. Sedangkan jiwa-jiwa yang menolak Yesus akan masuk ke siksaan api neraka sementara bersama-sama dengan orang-orang dari zaman Nuh yang juga menolak Kristus (1 Ptr 3:20). Sesudah itu mereka akan dihukum untuk selama-lamanya di lautan api kekal (why 20:15). Roh dan jiwa mereka dibawa oleh malaikat ke satu tempat yang dalam Alkitab disebut "Dunia Orang Mati" atau "alam maut."9

Oleh karena itu, ayat-ayat tersebut menunjukkan bahwa roh orang mati tidak bisa berjalan sesukanya. Namun mereka tetap dikawal, jadi arwah orang mati bersikap pasif tidak tidak mempunyai pilihan lain, ia harus menuruti malaikat yang membawanya. Tidak ada kesempatan untuk beralih pilihan, masa ini sedang menunjukkan siapa yang akan mengalami kebahagian dan siapa yang menderitan tidak ada pilihan lain. sebab penentuanya di waktu hidup, setelah mati tidak bisa bersikap aktif dengan kata lain diatur atau mereka akan dikomando oleh malaikat yang ditugaskan Tuhan untuk menempati tempat yang ditetapkan oleh Allah sendiri istilah yang dipakai oleh Alkitab untuk memberikan penjelasan tentang dunia orang mati adalah "sheol" dalam Perjanjian Lama atau "Hades" dalam Perjanjian Baru. Untuk lebih jelasnya pengertian tentang istilah tersebut penulis akan mendefinisikan setiap istilah tersebut.

\section{Istilah Sheol (PL) dan Hades (PB)}

Dalam Perjanjian Lama Istilah yang dipakai untuk "Alam Maut" adalah "Sheol" yang disebutkan sebanyak 65 kali. Perjanjian Baru menyebutkan sebanyak 42 kali dan kata yang dipergunakan dalam bahasa Yunani adalah "Hades." 10 Kata itu mengacu pada tempat tinggal setelah mati bagi orang-orang tidak benar. Pada umumnya keberadaan orang-orang yang mati dalam masa Perjanjian Lama dijelaskan dengan kata Ibrani " yarad" yang artinya turun ke tempat dunia orang mati atau sheol. Misalnya, ketika Korah dan para pengikutNya memberontak melawan Musa di padang gurun, Allah menghukum mereka dengan cara membuka tanah, sehingga mereka dan semua harta miliknya terperosok ke dalam lubang tersebut.

\footnotetext{
${ }^{9}$ Ibid 313

${ }^{10}$ Ibid halaman 314
}

\section{Pengertian Sheol}

Alkitab berkata bahwa mereka jatuh ke dalam Sheol: Demikianlah mereka dengan semua orang yang ada pada mereka turun hidup-hidup ke dunia orang mati (Sheol); dan bumi menutupi mereka, sehingga mereka binasa dari tengah-tengah jemaah itu. (Bilangan 16:33, Ayub 7:9). Sheol berasal dari bahasa Ibrani adalah tempat orang mati yang berada di bagian bumi yang paling bawah. Dalam septuangginta kata sheol di terjemahkan hades. ${ }^{11}$

Dan penjelaskan ini dikuatkan lagi oleh Laird Harris, juga mengajarkan bahwa sheol adalah tempat orang mati yang berada di bagian bumi yang paling bawah. ${ }^{12}$ Lalu dalam sejarah Israel, Allah ingatkan mereka bahwa murka Allah memperkuat nyala api yang membakar Sheol: Sebab api telah dinyalakan oleh murka-Ku, dan bernyala-nyala sampai ke bagian dunia orang mati yang paling bawah; api itu memakan bumi dengan hasilnya, dan menghanguskan dasar gunung-gunung. (Ulangan 32:22, tambahkan penekanan).

Raja Daud menyatakan bahwa, Orangorang fasik akan kembali ke dunia orang mati (Sheol), ya, segala bangsa yang melupakan Allah. (Mazmur 9:17,). Dan ia berdoa untuk menghadapi orang-orang yang tidak benar dengan memohon, Biarlah maut menyergap mereka, biarlah mereka turun hidup-hidup ke dalam dunia orang mati (Sheol)! Sebab kejahatan ada di kediaman mereka, ya dalam batin mereka. (Mazmur 55:16, tambahkan penekanan). Untuk mengingatkan orang muda akan tipuan wanita sundal, Salomo menuliskan, Rumahnya adalah jalan ke dunia orang mati (Sheol), yang menurun ke ruangan-ruangan maut. Penjelasan Ayat-ayat Alkitab di atas dapat meyakinkan kita bahwa Sheol sudah ada dan menjadi tempat siksaan di mana orang-orang tidak benar dikurung setelah mereka mati. Dan dalam Perjanjian Baru dapat meneruskan pengertian ini untuk menjelaskan bahwa tidak ada perbedaan isi Alkitab, makna yang terkadung di dalamnya dengan Perjanjian Baru di masa pelayanan Tuhan Yesus dan para murid. Istilah yang di pakai untuk menjelaskan dunia orang di sebarkan dengan istilah "Hades" kata ini merupakan terjemahan dari septuaginta/ LXX, yaitu terjemahan dari bahasa Ibrani ke bahasa Yunani. Untuk dapat dipahami secara rinci penulis akan menjebarkan dengan mendefinisikan istilah tersebut.

${ }^{11}$ H.Marril, Eugene, "Sheol" dalam Dictionary of old testament, (Wheaton: Victor Book,1985) 4:6l

12 Laird Harris "Sheol" dalam Theological

Wordbook of the old Testament,(Chicago Mooody Pres, 1980), 892. 


\section{Pengertian Hades}

Hades, kata bahasa Gerika dalam Perjanjian Baru, mengacu pada tempat yang sama dengan kata bahasa Ibrani dalam Perjanjian Lama, Sheol. Untuk bukti hal ini, kita bandingkan Mazmur 16:10 dengan Kisah Para Rasul 2:27, berikut ini: Sebab Engkau tidak menyerahkan aku ke dunia orang mati (Sheol), dan tidak membiarkan Orang Kudus-Mu melihat kebinasaan. (Mazmur 16:10,). Sebab Engkau tidak menyerahkan aku kepada dunia orang mati (Hades), dan tidak membiarkan Orang Kudus-Mu melihat kebinasaan. (Kisah Para Rasul 2:27,). Dengan demikian, dalam sepuluh contoh di mana kata Hades disebutkan dalam Perjanjian Baru, kata itu selalu dibicarakan dalam arti negatif dan sering disebut sebagai tempat penyiksaan orangorang jahat yang dikurung setelah mati (Matius 11:23; 16:18; Lukas 10:15; 16:23; Kisah Para Rasul 2:27; 2:31; Wahyu 1:18; 6:8; 20:13-14). Dari semua penjelasan ayat-ayat Alkitab di atas menunjukkan bahwa Sheol/Hades dulu dan sekarang itu sama tidak ada perbedaan yang adalah tempat bagi orang-orang sudah meninggal setelah mereka mati, ada suatu tempat bagi mereka untuk dihuni.Pertama, diungkapkan oleh Dale Moody bahwa hades adalah tempat atau status sementara untuk orang-orang jahat. Pandangan kedua dipegang oleh Geerhardus Vos, L. Berkhof, Joachim Jeremias dan A. Hoekema, yang menyatakan ada dua penggunaan yang berbeda dari hades dalam Perjanjian Baru, yaitu penggunaan abstrak dan yang lain adalah penggunaan lokal. Dalam penggunaan abstrak hades berarti "status kematian atau keberadaan tanpa tubuh" (Why. 6:8; 20:13). Sedangkan dalam penggunaan lokal, hades berarti tempat di mana orang-orang jahat dikumpulkan selama intermediate state (Luk. 16:23; Mat. 11:23; 16:18). ${ }^{13}$

Dan penjelasan ini juga makin berkembang dalam dunia teologi secara khusus tertuju pada tempat didikan penulis dunia orang mati sangat jelas dalam doktrin eskatologi. Penjelasan Lois Berkhof ketika dunia Hades dipandang dari segi abstrak itu tertuju pada konsep kematian yang barlaku bagi semua orang tetapi jika dipandang dari segi lokal maka Hades tertuju pada tempat penyiksaan bagi orang-orang jahat. Dunia orang mati dalam Bahasa Ibrani sebagai bahasa PL mengunakan istilah Sheol $=$ Hades (PB Yun) (sama artinya) tempat tinggal di bawah bumi untuk semua yang mati sampai penghakiman. Sheol dibagi menjadi dua : Sheol atas $=$ surga $/$ pangkuan Abraham $=$ paradise

${ }^{13}$ Stephen H. Travis, Christian Hope \& the Future (Downers Grove: InterVarsity, 1980) 110. (firadaus/ taman surga TUHAN) Sheol bawah = Gehenna /neraka untuk yang jahat istilah Neraka Gehena adalah suatu tempat yang jauh dari dunia, ditepi alam semesta (Mat 6:12, 22:13, II Pet 2:17, Yud 13). Perjanjian Baru menggunakan Gehenna untuk berbicara dari tempat penghakiman terakhir.Gehenna $=$ terjemahannya "lembah ratapan/rengekan" Perjanjian Baru gehena = neraka. Bahasa PL nya (Ibrani) : "Hinom" Sejarah istlh tempat namanya "Hinom" (Bagian selatan lembah di Yerusalem Yos 15:8; 18:16; 2 Taw 33:6;.. Yer 32:35) menjadi tempat pengorbanan anak untuk dewa Molokh (dibakar mati) "Hinom" di Yerusalem "lembah sempit yang akhirnya jadi tempat pembakaran sampah. ${ }^{14}$

Dengan penjelasan tersebut kita dapat memahami bahwa istilah sheol dalam Perjanjian Lama atau hades dalam Perjanjian Baru tidak ada perbedaan makna dan penting untuk di pahami bahwa Sheol atau Hades, bukanlah neraka tetapi tempat penantian semenatara bagi jiwa-jiwa orang yang tidaka benar di mata Tuhan. Sangat penting untuk dipahami oleh setiap pembaca skripsi ini, bahwa dunia orang mati bukanlah Neraka. Karena Neraka baru dipergunakan pada akhir zaman setelah pengadilan taktah putih besar. Dunia orang mati lebih bersifat sebagai "tempat penantian" sebagaimana arwah orang mati ditempatkan untuk sementara sambil menunggu hari penghakiman.

Karena pembuktian secara lengkap menerangkan bahwa Sheol atau hades bukan menunjuk pada sorga, melainkan tempat orang mati yang berada di pusat bumi. Ini di jelaskan dalam Bilangan 16:33 dan Efesus 4:9. ${ }^{15}$ Karena sheol dalam Perjanjian Lama menjelaskan bahwa keberadaan manusia tidak berakhir dengan kematian secara fisik atau badani, tetapi mereka yang meninggal terus hidup di "alam bawah". Dan mereka bukan "nyawa yang punah". Tetapi hanya memiliki sedikit substansi. Dan juga dalam penegasan-penegasan keseluruhan Perjanjian Baru dengan tegas membedakan antara alam maut (hades) status perantara, dan neraka (Gehenna), yaitu tempat hukuman akhir. ${ }^{16}$ Oleh karena itu, istilah yang digunkan untuk menjelaskan konsep dunia orang mati adalah sheol atau yang diterjemahkan dalam septungginta "hades" menunjuk pada suatu tempat untuk jiwa dan roh orang yang sudah meninggal untuk menanti kapan

\footnotetext{
(STTII Surabaya), 27

${ }^{15}$ Welly Pandensolang Eskatologi Teologi

Biblika (Yayasan Andi, Yogyakarta. 2004), 89

${ }^{16}$ George Eldon Ladd Teologi Perjanjian Baru
}

${ }^{14}$ Dr. Johnathan Octavianus, Diktat Eskatologi.

(Kalam Hidup, Bandung 2012). 256. 
tibanya waktu penghakiman. Bagi yang belum diselamatkan pada saat kematian rohnya langsung pergi ke Sheol/ Hades ini. Ruang tunggu yang setara dengan "neraka" tetap tunggu untuk "penghukuman kekal" di akhir zaman (Wah 20) karena masalahnya mereka itu belum dihakimi.

\section{Lokasi Sheol Atau hades}

Untuk dapat memberikan pengertian yang jelas tentang lokasi Sheol atau Hades harus diketahui bahwa itu merupakan hal yang sangat sulit sebab memang secara alami tidak ada yang dapat menemukannya sucara langsung, tetapi untuk dapat dipahami ekseget menemukan sumbangsi yang dapat dipertanggungjawabkan dengan benar dan terbukti melalui penelitian yang mendalam serta teruji dengan teologia yang murni dan jujur terhadap Alkitab. Maka dalam hal ini sekalipun banyak umat manusia yang masih sulit untuk memahami, dihimpit oleh keraguan karena tidak dapat mempertanggung jawabkan dengan benar. Namun penjelasan yang dituangkan oleh Dr. Jonathan Octavianus, tentang lokasi Sheol atau Hades cukup menolong ekseget untuk dapat memahami konsep tentang lokasi dunia orang mati ia mengatakan:

Pandangan Yahudi Kuno. Tentang sheol dapat dijelaskan dengan kata yarad dalam Perjanjain Lama yang berarti "turun" ke dalam dunia orang mati yang digunakan untuk Korah dan pengikutnya ketika memberontak melawan Musa mereka diterkam bumi, maka lokasi dunia orang mati, sheol atau hades adalah tempat penantian di pusat bumi dalam kondisi yang terpisah dari dunia nyata ke dunia roh. Dan mereka sudah tidak beraktifitas dalam hal apapu selain dari penantian waktu yang Tuhan tentukan.Pandangan Yunani kuno Hades = Orcus/inferna: tempat untuk semua yang mati, Lokasinya : di kedalaman bumi, gelap, suram, muram, tidak dapat diakses walau dengan doa dan pengorbanan/ korban. Tempatnya diperintah oleh "Pluto" (dewa ketua musuh dari semua yang hidup). Dewa yang tidak punya perasaan, yang tidak bisa ditawar-tawar dan dibenci dewa lain dan manusia. ${ }^{17}$

Berdasarkan bukti penjelasan dari Dr. Jonathan Octavianus, kegunaan istilah "yarad" dalam bahasa asli Alkitab bahasa Ibrani dapat menjelaskan cara kepergian setelah mati, jiwa-jiwa itu terun ke dalam bumi, maka dengan jujur mengatakan bahwa lokasi Sheol atau Hades berada di dalam perut bumi. Laird Harris juga mengajarkan bahwa Sheol adalah tempat orang mati yang berada di bagian bumi yang

${ }^{17}$ Jhonatan Octavianus Diktat Eskatologi (STTII paling bawah. ${ }^{18}$ Maka tidak ada keraguan untuk menerima penjelasan ini sebagai dasar untuk mengakui bahwa keberadaan jiwa-jiwa yang sudah meninggal sedang berada di dalam perut bumi.

Pembuktian secara lengkap menerangkan bahwa Sheol atau Hades bukan, mwlainkan berada dipusat Bumi terungkap dalam Bilangan 16:33. Telah menerangkan bahwa orang-orang berdosa yang menerima hukuman dari Allah dalam Perjanjian Allah masuk kedalam Sheol. Keterangan di dalam ayat ini dinyatakan melalui kata wattekas, dengan konstruksi piel preterit waw konsekutif imperfek, yakni kaidah gramatikal bahasa Ibrani yang menjelaskan suatu tindakan aktif dan pasti yang dilakukan pada masa lampau ". Istilah wattekas berasal dari kata kerja kasa yang artinya "menutup". 19

Dengan demikianbentuk piel dari kata itu menerangkan bahwa bumi secara intensif menelan dan menutupi dari atas orang-orang mati itu untuk menuju Sheol, yaitu bagian bumi yang paling bawah. ${ }^{20}$ Berdasarkan bukti-bukti penegasan yang telah penulis kutip dari penjelasan setiap tokohtokoh teolog di atas dijadikan sebagai dasar yang dapat meneguhkan keyakinan akan keberadaan dunia orang mati, status dan posisinya sangat jelas berada di dalam bumi.

\section{Istilah Neraka}

Untuk istilah neraka lebih banyak ditemui dalam Perjanjian Baru, yang ditinjau dari segi kondisi tidak berbeda dengan kondisi yang dialami dalam Sheol atau hades, namun jika ditinjau dari tempat Neraka berbeda dengan Sheol atau Hades, dengan alasan jiwa-jiwa hanya tinggal sementara di Sheol dan telah itu mereka di hakimi untuk masuk ke Neraka. Dr. Jonathan Octavianus mengatakan,

"Dipakai dalam Perjanjian Baru kata gehenna ("neraka") idenya untuk orang yang jatuh berkali-kali (sudah dapat peringatan) dan konsekuensi dari dosa (Mat 5:22, 29-30; 10:28; 18:9; 23:15, 33; Mark 9:43, 45, 47, Luk 12:5) Tartaros(suatu tempat khusus di Gehena) tempat malaikat-malaikat yang jatuh (II Pet 2:4).Sebab

${ }^{18}$ Laird Harris Sheol dalam Theological Wordbook of the Old Testament, Peny, R Laird Harris (Chocago: Moody Press , 1980), 892.

${ }^{19}$ John Joseph owens, Analytical Key to the Old Testament (Grand Rapisd: Baker Book House, 1999), 1:653

${ }^{20}$ Eugene H. Merril "Numbers" dalam The Bible Knowledge Commentary, Peny John F. Walvoord dan Roy B Zuck (Wheaton: Victor Book,1985),235 
jikalau Allah tidak menyayangkan malaikat-malaikat yang berbuat dosa tetapi melemparkan mereka ke dalam neraka dan dengan demikian menyerahkannya ke dalam gua-gua yang gelap untuk menyimpan mereka sampai hari penghakiman; Tartaros juga terdapat dalam Surat Yudas 6. Dan bahwa Ia menahan malaikat-malaikat yang tidak taat pada batas-batas kekuasaan mereka, tetapi yang meninggalkan tempat kediaman mereka, dengan belenggu abadi di dalam dunia kekelaman sampai penghakiman pada hari besar....Istilah tartaros Yunani klasik : merujuk ke daerah bawah tanah, muram dan gelap, yang dianggap oleh orang Yunani kuno sebagai tempat tinggal orang mati jahat ketika mati. Hal ini dianggap sebagai tempat penghukuman. Dalam penggunaan tunggal dari kata ini dalam Perjanjian Baru mengacu pada tempat penghukuman bagi malaikat pemberontak. (malaikat yang jatuh/ nerakanya setan). ${ }^{21}$

Jadi berdasarkan penjelasan yang di sebarluaskan oleh Dr. Jonathan Octavianus, memberikan suatu pencerahan untuk dapat membedakan perbedaan anatara Sheol atau Hades dangan Neraka, jika diteliti dengan baik kita dapat membedakan bahwa Sheol tempat penantian bersama-sama semua orang yang sudah mati tetapi jika jiwa sudah menempati Nereka berarti sudah menempati posisi perpisahan kekal antara Allah dengan jiwa-jiwa yang sudah disahkan masuk Neraka.

\section{Istilah 'Pangkuan Abraham' Dalam Lukas 16:19-31}

Penjelasan tentang pangkuan Abraham kita tidak bisa tefsirkan secara literal sebab tidak mungkin pangkuan Abraham mampu untuk menampung seluruh orang yang percaya. Penjelasan menurut Alkitab Abraham adalah bapak orang beriman yang menjadi aikon atau pembuka jalan bagi orang percaya untuk mengenal Allah yang benar. Pangkuan Abraham bukanlah arti yang sebenarnya,hanya menggambarkan kedekatan seseorang yang telah menang dalam peperangan (iman) dengan Abraham. Karena kita semua tahu bahwa Abraham adalah Bapak orang percaya (Roma 4:11, 16; Galatia 3:7). Pangkuan Abraham ini disebut juga Firdaus oleh Tuhan Yesus (Lukas 23:43).

Penjelasan ini berdasarkan panggilan Tuhan kepada Abraham (Kej.12: 1-3), bahwa Abraham bukan hanya menjadi berkat secara jasmani saja tetapi secara rohani ia menjadi berkati bagi

${ }^{21}$ Jhonatan Octavianus Diktat Eskatologi (STTII banyak orang. Abraham juga menjadi contoh untuk orang beriman (Ibrani 11:8-19), dan bukan hanya itu saja tetapi Alkitab membuktikan bahwa Abraham menjadi bapa bagi seluruh orang yang beriman dijelaskan dalam (Roma 4:16-23). Oleh karena itu, istilah pangkuan Abraham tidak bisa ditafsirkan secara literal, karena bukan berbicara tentang tempat tetapi Alkitab menjelaskan suasana atau keberadaan Lasarus telah berada bersama Abraham. Dalm Injil Lukas 16:19-31, Kebanyakan penafsir sependapat kisah ini menyatakan implikasi yang jelas bahwa orang kaya tersebut jahat sebab ia tidak perduli dan tidak sensitif terhadap penderitaan orang-orang miskin yang ada di dekatnya.

Setelah kematian kedua orang tersebut, Alkitab tidak mengatakan bahwa Lazarus masuk ke dalam alam maut (hades) pada waktu ia mati, melainkan ia dibawa oleh malaikat ke pangkuan Abraham (ay. 22). Tetapi untuk orang kaya itu dikatakan, "ia menderita sengsara di alam maut, ia memandang keatas" (ay. 23). Dari kontras ini kita segera menangkap bahwa hades adalah suatu tempat penyiksaaan dan penderitaan bagi orang-orang yang tidak benar, sedangkan "pangkuan Abraham" adalah suatu tempat atau keadaan yang berkebalikan dengan hades, yaitu tempat kebahagiaan orangorang yang dibenarkan Allah (ay. 25). ${ }^{22}$

Penjelasan para penafsir ini memberi titik terang penjelasan mengenai pangkuan Abraham bahwa itu bukan secra literal tetapi menunjuk pada tempat yang penuh dengan kebahagian bagi mereka yang dibenarkan oleh Allah, pangkuan Abraham juga sedang menggambarkan kedekatan orang percaya kepada Yesus Kristus setelah meninggal dunia mereka dikumpulkan bersama-sama dengan semua orang yang beriman. Dan dalam bahasa Yunani pangkuan Abraham kata yang dipakai dalam topik ini adalah kata "Firdaus" adalah kata Yunani yang berasal dari bahasa Persia yang berarti "taman" atau "kebun." 23 Dalam Perjanjian Lama kata ini digunakan dalam Yehezkiel 28:13; 31:8, "Taman Eden". Dalam tulisan orang-orang Yahudi yang lebih akhir, kata ini menunjukkan tempat di mana orang-orang benar diberkati di masa antara kematian dan kebangkitan. Dalam 2 Korintus 12:4, Paulus mempergunakan kata Firdaus sebagai tempat tinggal Allah, "ia tiba-tiba diangkat ke Firdaus."

Dalam kegunaan kata " Firdaus" dalam Injil Lukas 16 : 22b dengan istilah pangkuan Abraham di pakai oleh Tuhan Yesus pada waktu percakapan dengan seorang penjahat yang

${ }^{22}$ Intermediate State in the New Testament (Holand: Franeker, 1966) 197.

${ }^{23}$ Loraine Boettner, Immortality (Philadelphia: Presbyterian \& Reformed, 1967) 34-35. 
disalibkan bersama-sama dengan Dia dalam (Lukas 22:14). Yesus menjawab, "Aku berkata kepadamu, sesungguhnya hari ini juga engkau akan ada bersama-sama dengan Aku di dalam Firdaus". ${ }^{24}$ Penjahat itu tidak mengharapkan untuk diingat segera namun jawaban Yesus "hari ini" melebihi apa yang ia minta. Yesus mengundangnya untuk menikmati persekutuan dengan-Nya di hadirat Allah "hari ini," yakni segera setelah kematian. Sebagai orang percaya, kita semua hidup dalam peperangan iman di dalam dunia ini. Ada saatnya kita semua harus pulang kepada Bapa ketika saatnya tiba. Sebelum kita mendapatkan tempat di sorga semua orang yang percaya akan dikumpulkan di suatu tempat penantian. Tempat ini disebut oleh Tuhan Yesus sendiri sebagai Pangkuan Abraham/Firdaus karena Abraham adalah Bapak semua orang percaya, dia adalah sahabat Allah. Disana kita akan disambut oleh Bapak orang percaya, yaitu Abraham karena telah menang dalam peperangan iman. Pangkuan Abraham/Firdaus adalah tempat penampungan sementara orang yang percaya Yesus.

Pangkuan Abraham/Firdaus ini disediakan Tuhan bagi orang-orang percaya yang telah menang dalam menghadapi peperangan iman di dunia, sedangkan untuk orang-orang yang kalah disediakan tempat bernama "alam maut" yang merupakan awal penderitaan sebelum ke neraka (Lukas 16:23). Dasar untuk bisa hidup bahagian seperti yang dialami oleha Abraham dan Lasarus mereka adalah orang-orang yang beriman. Pangkuan Abraham menunjuk pada tempat dimana roh-roh orang ditebus menunggu sampai hari kebangkitan Kristus diduga ini adalah tempat yang sama dengan Firdaus. Dan tempat itu bukan surga tetapi merupakan satu bagian dari dunia orang mati (sheol). ${ }^{25}$ kehidupan di Sheol / hades, dan Firdus yang sekarang ini ditempati, tidak bersifat kekal, tetapi bersifat sementara.

\section{Status Sementara}

Istilah status sementara ini mencakub banyak pengertian yang di ungkapkan bertujuan menjelaskan kepada umat manusia mengenai kehidupan di dunia ini, tempat setelah meninggal. Karena bila kita meninggal kita belum bisa berada ditempat kekekalan sebelum parousia (kedatangan kedua kali). Namun status sementara menjelaskan kehidupan di

${ }^{24}$ Anthony A. Hoekema, The Bible and the Future (Grand Rapids: Eerdmans, 1979) 103.

${ }^{25}$ Gleason L. Archer Encyclopedia of Bible Difficulties (Malang Gandum Mas.2009), hlm. 627 dunia ini hanya sesaat saja. Hal ini telah diungkapkan dalam kitab mazmur 119:19. Hanya untuk sementara aku tinggal di dunia, kehidupan di bumi adalah suatu penugasan sementara, Alkitab banyak memjelaskan kehidupan di muka bumi ini bersifat singkat, sementara, dan fana. Dan dalam kehidupan ini juga menawarkan banyak pilihan yang berhubungan dengan kekekalan yaitu hidup di surga dan neraka itu baru dikatakan tempat yang kekal. ${ }^{26}$

Penentuan untuk hidup di surga atau neraka di tentukan saat masih hidup di dunia yang sementara ini dalam bentuk fisik bukan roh. Status sementara juga di tujukan pada tempat tinggal orang-orang yang sudah meninggal dalam ungkapan secara umum baik yang percaya Yesus Kristus dan yang tidak percaya Yesus mereka sedang menanti tempat kekekalan menurut pilihan masing-masing. Status orang percaya setelah kematian adalah berbeda dan lebih baik dari pada pengalman kita di dalam hidup ini. Dikatakan status sementara karena mereka mengalami perubahan hidup dari dunia nyata, menjadi dunia roh.Status sementara ditujukan kepada tempat penantian mereka sebab tidak selamanya mereka tinggal di hades, tetapi akan di bangkitkan kembali pada waktu akhir zaman... di dalam status sementara ini juga kita akan menikmati kelanjutan kesadaran kita sebagai pribadi yang ada di dalam kehadiran Kristus. ${ }^{27}$

Maka kematian itu bukan merupakan akhir dari segalanya tetapi, dari kehidupan yang nyata, tetapi kematian itu menunjukan adanya perbedaan status. Dari dunia nyata mereka telah masuk ke dunia roh yang tidak dapat dilihat oleh kasat mati jasmani.Herbert Lockyer menulis "Di alam maut ia memandang ke atas" (16:23). Alam maut ini (dalam bahasa Yunani, Hades) bukan suatu tempat penderitaan yang kekal, tetapi suatu tempat tinggal yang terkutuk untuk orang-orang mati. Dalam bahasa Ibrani ialah Sheol, Lazarus berada dalam "pangkuan Abraham" temapt tinggal yang bahagia untuk orang-orang suci yang mati dari saat mereka meninggal dunia sampai saat kebangkitan orang mati. ${ }^{28}$

Dalam penjelasan Herbert Lockyer, makin memperjelas status orang-orang mati yang berada

\footnotetext{
${ }^{26}$ Rick Warren The Purpose Driven Life

(Malang, Gamdum Mas 2006).40

${ }^{27}$ R.C. Sproul Kebenaran-Kebenaran Dasar
}

Iman Kristen ( Malang, Seminari Alkitab Asia Tenggara,

2002)274.

${ }^{28}$ Herbert Lockyer, All The Prabeles Of The Bible (Grand Rapids: Zondervan, 1963), 291 
dalam Sheol atau Hades bahwasannya mereka hanya tinggal dalam sementara waktu untuk menanti kapan tiba waktu kebangkitan. Dasar pengajaran yang disebarluaskan untuk meyakinan umat manusia bukan terletak pada raio tetapi dari Alkitab.

\section{Status Kekal}

Status sementara muncul oleh karena sudah ada keberadaan yang kekal yang dijelaska dalam Alkitab, bukan dikarang oleh akal manusia. Tetapi semuanya yang terungkap dan berhubungan dengan kekekalan Alkitab telah menyatakan semuanya.Untuk memahami istilah kekal yang digunakan dalam Alkita, akan dijelaskan dalam kutipan berikut ini:Terdiri dari dua kata Yunani yang sering diterjemahkan sebagai kekekalan yang pertama athanasia dan aphtharsia .Athanasia hanya di pakai tiga kali dalam Perjanjian Baru, satu kali dalam I Timotius 6:16 dan dua kali dalam satu Korintus 15:53-54. Dalam ayat yang pertama kata ini dipakai untuk menggambarkan Allah sebagai "satusatunya yang tidak takluk kepada maut, bersemayam dalam terang yang tidak terhampiri... menjelaskan bahwa kekekalan Allah yang di maksudkan bukan hanya sekedar menunjukkan keberadaan yang tidak akan berakhir. Namun kekekaln yang dimaksud adalah yang orisinal bukan yang diberikan. Dan kata yang kedua athanasia dikenakan kepada manusia. Karena kita yang dapat binasa dikenakan yang tidak binasa atau tidak mati. Kekekalan ini diberikan dari Allah bagi orang percaya. ${ }^{29}$

Dalam kutipan di atas, Rasul paulus menjelaskan tiga hal tentang kekekalan. Yang pertama, kekekalan yang penuh kebahagian itu diberikan hanya kepada orang beriman. Tidak menyinggung tentang orang yang tidak percaya. Yang Kedua, kekekalan ini diteriman dimasa yang akan datang. Yang ketiga, Kekekalan yang digambarkan disini bukan karakteristik yang hanya dimiliki oleh jiwa, tetapi keseluruhan pribadi secara utuh (I Korintus 15:52-55). Dan tidak dikuasai oleh maut, tetapi menang atas maut. Sehingga orang yang percaya kepada Yesus Kristus sebagai tuhan dan juruselamat mereka tidak di kuasai maut melainkan mereka telah dipindahkan dari dalam maut ke dalam hidup yang kekal oleh karena mereka telah mendengar dan percaya kepada Yesus Kristus (Yoh 5:24). Maka tindakan orang untuk percaya kepada

${ }^{29}$ Anthony A. Hoekema Alkitab dan Akhir Zaman
Yesus itu harus berlandasakan atas pengakuan dan menerima Tuhan Yesus secara pribadi tidak ada sistim perwakilan.

\section{Tidak Ada Komunikasi Dengan Roh Orang Mati}

Konsep ini sangat terpeting untuk dimengerti dengan jelas bahwa dalam Alkitab sangat menegaskan bahwasannya didalam Alkitab tidak mandat untuk mengadakan komunikasi dengan roh orang mati. Sebab roh orang yang sudah meninggal, Tuhan telah menyediakan tempat bagi mereka, namun dalam perkembangan pengajaran banyak yang salah memahami isi Alkitab, sehingga banyak penyembahan-penyembahan berhal disetiap suku karena mereka telah menjaling hubungan komunikasi dengan roh orang yang sudah meninggal. Maka hal ini dijelaskan dalam kitab Ulangan 18:10 -12, tertulis diantara kamu janganlah didapati seorangpun yang mempersembahkan... atau seorang yang bertanya kepada arwah kepada roh peramal atau yang meminta petunjuk kepada orang mati. Sebab setiap orang yang melakukan hal itu adalah kekejian bagi Tuhan. Jadi Tuhan sangat tegas melarang tidak boleh memanggil arwah orang mati. $^{30}$

Penyalingan hubungan dengan arwah orang mati merupakan tindakan berhala terhadap Tuhan sebab setiap orang yang menduakan Allah dengan sesuatu apapun juga itu sudah termasuk penyembahan berhala. Keluarana 20:3. Jangan ada padamu allah lain dihadapan-Ku. Dalam sepuluh hukum taurat, hukum yang ketiga dengan tegas melarang. Namun kebanyakan umat mempercayai masih ada hubungan dengan arwah orang yang sudah meninggal, karena yang menjadi alasan bagi mereka adalah pada saat orang keserupan mereka berkomunikasih dengan arwah tersebut. Maka hal inilah yang membuata mereka semakin yakin. Namun alasan ini sangat bertolak belakangan dengan Firman Tuhan berkata bahwa roh orang mati dibawah oleh malaikat ke hades bagi yang tidak percaya Yesus dan mereka dipenjarakan disana. Sehingga tindakan untuk berkomunikasi dengan roh orang mati tidak ada dasar Alkitabiah yang jelas, dasar penolakan Alkitab terhadap komunikasih dengan roh orang mati sangat terbukti dalam Lukas 16:29-31, sedang memberikan suatu pengertian bahwa mereka yang sudah mati tidak ada kesempatan bagi mereka untuk membawa berita

\footnotetext{
${ }^{30}$ Darmawan S.Bone. Memerintah Sebagai Raja
} 
bagi keluarga mereka. Sehingga Dr. Rebecca Brown, menjelaskan penolakan terhadap sikap pemanggilan roh orang mati sebagai berikut:

Dr. Rebecca Brown menulis: acara memanggil roh orang mati adalah dusta belaka. Dalam acara pemanggilan roh, pemanggil arwah sebenarnya tidak dapat memanggil roh orang mati. Firman Tuhan menunjukan kepada kita bahwa mereka hanya memperalat roh-roh jahat yang mereka panggil dan menyuruh mereka untuk bertingkah dan memperagakan diri sebagai orang yang sudah mati itu. Memang Iblis dapat membunuh manusia secara fisik, tetapi ia tidak dapat menguasai jiwa dan row mereka setelah mereka meninggal. ${ }^{31}$

Dengan perkataan lain Dr. Brow tampaknya sependapat bahwa tanpa izin Tuhan roh orang mati tidak mungkin keluar dari dunia orang mati, sehingga dalam kutipan ini terbukti bahwa sebetulnya orang-orang yang menjaling hubungan dengan roh orang mati, mereka harus segera berbalik dari tindakan tersebut sebab roh yang berkomunikasi dengan mereka bukan orang yang mereka cintai setelah meninggal ia kembali untuk menjaling hubungan dengan keluarganya, melainkan roh jahat yang menyerupai orang tersebut supaya disembah oleh manusia, dan kita tidak perlu bingung dengan tindakan ini, jangankan manusia yang ditipu untuk menyembah dia, Tuhan Yesus dalam puasa 40 hari dan 40 malam, setelah selasai Ia berpuasa Iblis tahu kalau Ia secara manusia sejati lapar, maka iblis mencobai Dia. Cobalah kita memperhatikan Matius 4:8-9. Dalam cobaan yang ketiga ia membawa Yesus kegunung yang sangat tinggi dan memperlihatkan seluruh dunia dengan kemegahanya, dan ia berkata kepada-Nya: " semuanya itu akan ku berikan kepada-Mu, jika Engkau sujud menyembah aku. Dalam dialog ini kita dapat memahami bahwa iblis adalah bapak berambisi supaya disembah oleh manusia. Namun karean Yesus Kristus bukan saja manusia sejati tetapi Ia adakah Allah sejati juga sehingga iblis mundur bukan ditiadakan, tetapi ia menunggu waktu yang tepat.

Oleh karena itu, umat manusia harus sadari dengan baik bahwa yang menyerupai orang yang dicintai adalah roh jahat dengan ambisinya untuk disembah. Maka ketika ada yang memanggil roh orang yang sudah meninggal meyakini dalam bentuk keserupan ia sedang berusaha untuk menyembah iblis dalam ambisinya. Sebab Firman Tuhan mengatakan bahwa roh jahatlah yang masuk dalan tubuh seseorang bukan roh orang yang sudah

\footnotetext{
31 Dr,Rebecca Brow He Came To Set The
} Captioves Free, (Whitaker house Springdale . pensylvania, 1992) 283-284. meninggal. $^{32}$ Dialog antara Tuhan Yesus dengan orang yang di Gerasa sedang menunjukan bahwa iblis bisa merasuk manusia, bisa tinggal dalam manusia sepenuhnya, namun jiwa dan roh manusia ia tidak berkuasa atanya (Markus 5:1-13). Dengan demikian Yesus berdialog dengan roh jahat bukan roh orang mati, karena roh orang mati mereka tidak diijinkan Allah untuk keluar lagi dari tempat sementara yang sudah disediakan oleh Allah sendiri, bahwa bisa saja mereka dijaga oleh malaikat yang ditugaskan.

\section{Tidak Ada Keselamatan Setelah Kematian}

Kebanyakan pemahaman yang dapat mengartikan bahwa ada keselamtan setelah kematian berdasarkan ayat dalam Filipi 2:10. Ayat ini terkenal "Supaya dalam nama Yesus bertekuk lutut segala yang ada dilangit dan yang ada di atas bumi dan yang ada dibawah bumi" (Flp 2:10) menyatakan secra tak langusng bahwa kemungkinan ada pertobatan sesudah kematian, namun sebaliknya ayat tersebut menyiratkan suatu pengakuan akan kekuasaan tertinggi dan kemenangan Kristus . ${ }^{33}$ Oleh karena itu, yang memiliki keyakinan bahwa setelah meninggal masih ada kesempatan bagi orang yang memberontak melawan Allah dengan perbuatannya mereka akan disucikan untuk bisa masuk surga, memberikan harapan kepada manusia umunya. Namun dasar pemikiran yang semacam ini keliru, sebab dalam Alkitab tidak pernah mengajarakan bahwa orang yang sudah meninggal masih dapat kesempatan untuk bertobat.Tempat penderitaan adalah tempat yang khusus disediakan untuk penyiksaan bukan tempat untuk menyampaikan berita kebenaran injil. Sebab itu mereka yang sudah masuk kesana, tidak mempunyai harapan untuk keluar. Ini adalah berita tragis tetapi tragedi tidak akan mengrangi kebenaran Firman Tuhan. $^{34}$

Dalam kutipan tersebut terlihat bahwa di dalam dunia orang mati, bagi mereka yang meninggal dalam keadaan terikat dengan dosa artinya belum mendapat jaminanan pembebasan dari dosa, mereka sedang diperhadapkan dengan penghukuman, penyiksaan dalam api yang sangat panas. Oleh karena itu, nasib akhir manusia ditentukan pada waktu masih hidup. Sebab tidak

${ }^{32}$ Darmawan S.Bone. Memerintah Sebagai Raja (Kalimantan Timur STTT, 1998). 319

${ }^{33}$ George Sandison \& Staff Bible answers for 1000 Difficul Questions (Malang Gandum Mas. 2006), hlm 378

${ }^{34}$ Tim Lahaye Life In The Afterlife, (Tyndale House Publisher Inc. Wheaton, 1980), 35 
ada pengharapan akan kesempatan kedua untuk bertobat setelah kematian, dan tidak ada kesempatan penyucian seperti purgatori untuk memperbaiki kondisi kita dimasa yang akan datang. Bagi orang yang percaya, kematian adalah kebebasan secara langsung. ${ }^{35}$ Berdasarkan pengertian diatas dapat memberikan penjelasan bagi kita bahwa, setelah kita meninggal tidak ada lagi kesempatan untuk diselamatkan. Karena pada waktu, kita meninggal jalan pertobatan tertutup untuk selama-lamanya! ${ }^{36}$ Karean pertobatan itu terjadi saat masih menjadi daging dalam dunia nyata kalau sudah menjadi roh tidak bisa bertobat lagi.

Pertobatan dalam bahasa Yunani adalah metanoia yang berarti " perubahan pikiran" pada waktu datang kepada Tuhan... pertobatan berarti berbalik dari jalan manusia untuk mengikuti jalan Allah. Bertobat juga berarti memiliki keinginan untuk menjadi milik Kristus dan untuk hidup sesuai dengan yang diperintahkan-Nya, maka pertobatan itu adalah bagian dari pada kesadaran akan dosa, artinya memiliki kerinduan untuk meninggalkan kehidupan lama dan memperoleh satu kehidupan baru di dalam Yesus Kristus (II Korintus 5: 17) ) $^{37}$

Sangat mustahil bagi mereka yang memiliki konsep bahwa masih ada kesempatan untuk memperbaiki hidup setelah meninggal Alkitab tidak menagatakan ada keselamatan bagi yang sudah meninggal sangat jelas dalam Luka 16:26 "Diantara kami dan engkau terbentang jurang yang tak tersebrangi supaya mereka yang pergi dari sini kepadamu ataupun mereka yang mau datang dari situ kepada kami tidak dapat menyebrang". Teks ini sangat jelas bahwa mereka yang sudah menerima hukuman tidak mungkin bagi mereka untuk berpin dah ke tempat yang penuh sukacita. Kosep ini mendapatkan dukungan yang kuat dari kutipann berikut:

Persoalan yang paling penting bukanlah apakah ada pertobatan setelah kematian, melainkan apakah pertobatan akan bermanfaat pada saat seperti itu. Manusia tidak mempenyai hak untuk membatasi kemurahan Allah, tetapi dalam Alkitab tidak ada yang mendorong manusia untuk berharap mengenai kesempatan memperoleh keselamatan sesudah kemataian. Setiap orang yang menunda pertobatan sampai pada waktu kematian, menghapi resiko yang mengerikan... tidak ada kesempatan untuk pertobatan setelah kematian tidak dapat dibuktikan secara

35 R.C. Sproul Kebenaran-Kebenaran Dasar Iman Kristen ( Malang, Seminari Alkitab Asia Tenggara, 2002)275.

Yakin 1989).25 mutlak, tetapi kecenderungan Alkitab selalu tertuju (Why 22:11), "Barangsiapai yang cemar biarlah ia terus cemar" dan seterusnya ${ }^{38}$

Penjelasan yang dikemukakan oleh George Sandison, bertujuan untuk menentang pemahaman yang keliru menafsirkan Filipi 2:10, bawasannya masih ada kesempatan pertobatan bagi mereka yang sudah di Shoel atau Hades. Maka penjelasan ini tidak hanya selesai disini saja namun ia masih terus memberikan penjelasan dengan dasar ayat dalam Injil "Lukas 16:26, diantara kami dan engkau terbentang jurang yang tak terseberangi supaya mereka yang mau pergi dari sini kepadamu ataupun mereka yang datang dari situ kepada kami tidak dapat menyeberang". ${ }^{39}$ Berdasarkan penjelasan diatas makna yang kita peroleh sangat jelas bahwasanya benar-benar tidak ada kesempatan bagi arwah orang yang sudah meninggal untuk bertobat, karena kesempatan sudah ditutup oleh Allah dan mereka hanya menunggu waktu penghakiman, tindakan Allah dalam menghakimi arwah tidak berhubungan dengan keselamatan tetapi penyesahan untuk masuk "hukuman Akhir" berlaku untuk selama-lamanya bersifat kekal.

\section{Pengharapan Bagi Orang Percaya}

Yang menjadi pusat perhatian orang percaya adalah kedatanga Kristus yang kedua kali. Pengharapan ini berdasarkan janji yang Yesus ungkap kepada murid-murid dalam setiap pengajaran-Nya. Dan bukan hanya bagi muridmurid saja tetapi bagi setiap orang yang percaya ungkapan janji ini tetap berlaku untuk semua manusia. Hal ini, digambarakan dalam Titus 2:13. “ orang kristen yang menantikan "penggenapan pengharapan yang penuh bahagia, dan penyataan kemulian Allah yang Maha besar dan Juruselamat kita Yesus Kristus. Dan konsep ini dapat dikemukan oleh Anthony A. Hoekema, tokohtersebut menuliskan pengertian yang mendalam yang berhubungan dengan pengharapan akan kedatangan yang kedua kali sebagai berikut:

Pengharapan tentang kedatangan yang kedua kali adalah aspek yang paling penting dari eskatologi Perjanjian Baru. Sedemikian petingnya sehingga iman jemaat didominasi oleh pengharapan ini. Isi Perjanjian Baru selalu mengarahkan pandangan manusia kepada kedatangan yang kedua kali, mendorong kita untuk senantiasa siap untuk menyambut kedatangan-Nya. Ia akan datang dalam

${ }^{38}$ George Sandison \& Staff. Bible Answers for 1000 Difficult Questions (Malang, Gandum Mas.2006), 378.

${ }^{39}$ George Sandison \& Staff. Bible Answers for 1000 Difficult Questions (Malang, Gandum Mas.2006), 379 
kemulian Bapa (Mat. 16:27); Yesus berkata kepada imam besara bahwa ia akan melihat Anak manusia duduk disebelah kanan yang Mahakuasa, (Mrk 14:62). Berkali-kali Yesus sampaikan kepada para pendengar untuk bersiap-siap menantikan kedatangan-Nya kembali, sebab Ia akan datang pada saat yang tak terduga (Mat 24:44; Luk 12:40.) ${ }^{40}$

Janji Tuhan Yesus tentang kedatangan-Nya yang kedua kali, di tekankan dalam peristiwa pada waktu Yesus mau terangkat ke surga, dan meninggal murid-murid, dan hati mereka yang penuh dengan kegelisahan, mereka sedang menatap ke langit pada waktu Yesus naik, Alkitab berkata, tiba-tiba berdiri dua orang yang berpakaina putih dekat mereka, untuk memperingatkan kembali janji Yesus bagi murid-murid, Yesus ini, yang terangkat ke sorga meninggalkan kamu, akan datang kembali dengan cara yang sama seperti yang kamu lihat Dia naik ke sorga (Kis 1:10-11). Para malaikat juga menjadi pembawa berita bahwa Yesus Kristus akan datang kembali. Mengenai kedatang yang kedua kali dalam surat-surat Rasul Paulus banyak yang tersampaikan tentang peristiwa itu, maka penulisan dalam (I Tes 5:2) karena kamu sendiri tahu benar-benar, bahwa hari Tuhan datang seperti pencuri pada malam! "Tuhan sudah dekat" (Flp 4:5). Mengenai kedatang yang kedua kali juga dijumpai dalam surat-surat umum. Penulis Ibrani berkata " Kristus mengorbankan diri-Nya satu kali untuk menghapus dosa, sesudah iitu Ia akan menyatakan diri-Nya sekali tanpa menanggung dosa, tetapi untuk menganugerahkan keselamata kepada mereka yang menantikan Dia" (Ibr 9:28). Dalam hal inilah, harus dimengerti dengan jelas bahwa peristiwa Kedatangan Kristus yang Kedua Kali (KKKK). Berkaitan erat dengan Iman atau pengharapan penuh kepada Yesus sebagai Tuhan dan Juruselamat, karena dalam kedatangan yang kedua kali untuk menjemput orang percaya atau gereja, pengharapan ini didasarkan atas kematian dan kebangkitan Yesus Kristus dalam Roma 10 :9, maka orang percaya memiliki kepastian hidup bersama Kristus. Inilah yang menjadi bagi iman Kristen tentang kedatangan yang kedua kali tidak ada satu titik pun untuk meragukan kebenaran akan "parosia" jika Alkitab yang menyatakan janji ini maka Alkitab juga yang akan menggenapinya.
${ }^{40}$ Anthony A. Hoekema Alkitab dan Akhir Zaman (Surabaya, Momentum, 2014).147-148

\section{Kebangkitan}

Dalam perasaan setiap umat Tuhan sangat pasti bahwa otomatis memiliki pengharapan akan kebangkitan dari kematian. Dan kebangkitan yang dimaksudkan adalah kebangkitan daging. Oleh karena itu, R. Soedarmo mengatakan, dalam pengakuan Iman Rasuli seluruh gereja mengakui ada kebangkitan daging, artinya maut bukanlah kebinasaan tubuh manusia melainkan perpisahan antara tubuh dan jiwa. ${ }^{41}$ Penjelasan ini menunjukan bahwa setelah kematian fisik masih ada kebangkitan daging.Kebangkitan dijelaskan dalam tiga istilah yaitu: Devotion artinya doa-doa atau tindakan nonliturgis, seperti jalan salib dan rosario yang mengembangkan kehidupan rohani seseorang dan memperdalam keyakinan iman. Yang kedua, Resurrection- arti dari istilah ini bukan hanya berarti hidup lagi seperti yang terjadi dengan anak Yairus (Mrk 5:22-24; 34-35), melainkan peralihan yang dialami oleh Tuhan Yesus melaui kematian ke dalm hidupnya yang sudah diubahkan dan abadi (Rm 1:34;I kor 15:42-50), yang menjadi jaminan bagi kebangkitan manusia. Yang ketiga, Resurrection of the dead-Kehidupan terakhir sesudah kematian yang disebabkan oleh kekuatan ilahi yang mencakup manusia seutuhnya (Tubuh dan jiwa). ${ }^{42}$

Jadi pengertian yang disebarluaskan dalam kutipan ini "kebangkitan" orang mati tidak termasuk dalam susunan liturgi sebab "kebangkitan" itu adalah tindakan Allah dalam menyatakan kuasa Ilahi-Nya bagi manusia ketika membangkitakan kembali manusia dari kematian untuk dihakimi, dan keadaan manusia pada saat kebangkitan akan bangkitkan dengan seutuhnya. Firman Tuhan berkata “ ... yang akan mengubahkan tubuh kita yang hina ini, sehingga serupa dengan tubuh-Nya yang mulia, menurut kuasa-Nya, yang dapat menaklukkan segala sesuatu kepada diri-Nya (Filipi 3:21) ${ }^{43}$ Kata "serupa" dalam bahasa Yunani adalah "summorphos" dapat diartikan " yang serupa". kata ini digunakan dalam Perjanjian Baru dua kali yaitu dalam Roma 8: 29 dan filipi 3:21. Sedangkan kata "tubuh-Nya" kata yang dipakai adalah "soma" artinya "tubuh" yang dipakai dalam Perjanjian Baru 14 kali untuk menjelaskan kata "tubuh". Dengan penegasan ayat ini tubuh yang dimiliki oleh orang percaya yang dibangkitakan "sama dengan tubuh kemulian Kristus". Atau tidak ada perbedaan.

\footnotetext{
${ }^{41}$ R. Soedarmo Kamus Istilah Theologia (Jakarta, Bpk. Gunung Mulia 1984), 46

${ }^{42}$ Edward G. Farrugia, Kamus Teologi (Yogyakarta, Kanisius, 1995), 133

${ }^{43}$ Darmawan S. Bone Memerintah Sebagai Raja (Kalimantan Timur, Sekolah Tinggi Teologia 1998), 326
} 


\section{Tubuh Kebangkitan Orang Percaya}

Harus diyakini bahwa pengertian kebangkitan orang percaya telah dilandaskan atas kebangkitan Yesus Kristus, proses kebangkitan dan kondisi tubuh yang dimili oleh orang Percaya jelas sama tidak ada perbedaan. Tubuh kebangkitan orang percaya mempunyai karakteristik atau sifat yang sama dengan tubuh yang dimiliki oleh Yesus setelah Ia bangkit dari kematian-Nya. Ia dapat masuk melalui pintu yang tertutup atau dinding. Tubuh seperti ini tidak lagi dibatasi oleh ruang dan waktu. Dan yang terutama sekali tubuh kebangkitan yang diperoleh umat percaya adalah tubuh yang kudus dan layak untuk masuk ke dalam surga. Tubuh ini tidak bisa mati lagi, tubuh ini masih mempunyai perasaan, emosi, hasrat dan sebagainya...tubuh ini masih bisa menakmati makanan (seperti Tuhan Yesus setelah ia bangkit makan bersama dengan murid-muridNya), namun tidak akan beranak cucu lagi atau tidak ada kawin-mengawinkan. (Mrk 12:25), sebab apabila seorang bangkit dari antara orang mati, orang tidak kawin dan tidak dikawinkan, melainkan hidup seperti malaikat disorga. ${ }^{44}$ Tubuh kemuliaan ini masih bisa menikmati makanan. Terlihat pada waktu Yesus bertemu dengan murid-murid, dan pertemuan di tepi pantai danau Tiberias, dan dua orang di Emaus, Yesus makan bersama-sama dengan mereka. Jadi dalam tubuh kemuliaan ini orang-orang yang percya kepada Yesus mereka masih bisa makan tetapi tidak berkeinginan.

\section{Kebangkitan Pertama}

Kebangkitan tubuh termasuk salah satu peristiwa eskatologis yang berhubungan erat dengan masa yang akan datang, tidak ada satupun manusia yang tahu tentang kapan tiba waktunya. Tujuan dari kebangkitan tubuh untuk menghadapi pengahakiman, bahwa Tuhan Yesus akan mengadili baik yang masih hidup pada waktu kedatangan-Nya kembali, maupun yang sudah mati. Oleh karena itu bahwa segala orang yang telah mati akan dibangkitkan untuk diadili (Yoh 5:29; Kis 24:15; Why 20:12-13). Kata Yunani yang digunkan untuk menjelaskan kata bangkita adalah " anastasis" yang artinya "bangunya, tetapi arti yang sebenarnya, adalah "peningkatan status atau peningkatan kondisi seseorang. Oleh karena itu, penjelasan ini jelas karena kebangkitan pertama dan kebangkitan kedua status mereka akan kekal jadi dari yang "fana" secara fisik akan ada peningkatan yaitu "kekekalan".Alkitab

\footnotetext{
${ }^{44}$ Ibid 327.
}

dengan jelas menyatakan bahwa Injil keselamatan menyerukan " bangunlah, hai kamu yang tidur dan bangkitlah hai kamu dari antara orang mati dan Kristus akan bercahaya atas kamu (Efesus 2:5-6). ${ }^{45}$ Ayat ini menjelaskan bahwa peristiwa yang akan terjadi saat Kristus datang Kedua Kalinya akan membangkitkan mereka yang memiliki pengharapan akan kedatangan Mesias sebagai penyelamat dalam masa Perjanjian Lama dan orang percaya yang mati, dibangkitkan terlebih dahulu. Penjelasan ini dikuatkan dalam (I Tes 4:15,16). Kedatangan-Nya ditandai dengan sebuah komando, dengan seruan, penghulu malaikat, dan bunyi sangkakala Allah. Pada saat itu orang-orang yang mati didalam iman kepada Kristus akan dibangkitkan untuk bersatu dengan jiwa-jiwa dan roh-roh mereka yang datang bersama Kristus dari surga (I Tes 4:14). Orangorang percaya yang masih hidup secara spontan diangkat dan menyongsong Tuhan di udara dan tanpa mati tetapi diubahkan dengan sekejap. ${ }^{46}$

Penggunaan waktu yang dipakai oleh Tuhan proses penjemputan ini di kenal dengan istilah dalamsekejap mata" karena digambarkan bahwa pada waktu ada dua orang sedang berbicangbincang tiba-tiba yang terangkat akan hilang dalam sekejap mati jadi yang tertinggal tidak melihat dalam proses waktu yang lama.Istilah ini dinyatakan dalan dua aspek yaitu: yang pertama "dalam waktu yang singkat. Alkitab bahasa inggris versi King James ditulis " In a moment " kata ini berasal dari bahasa Yunani " en atomo " yang secara harafiah berarti "dalam waktu yang sebesar atom". Arti yang kedua, "dalam sekejap mata" (bahasa inggris: "in the twinkling of an eye"). Juga berasal dari bahasa Yunani "Rhipe". Oleh karena itu istilah "en atomo" dan "Rhipe". Hanya dipergunakan satu kali dalam Perjanjian Baru yaitu dalam I Kor 15:52, untuk menjelaska proses perjumpaan Yesus kepada umatNya yang percya begitu sangat cepat prosesnya. ${ }^{47}$

Jadi peristiwa kebangkitan bagi mereka yang meninggal (mati), tidak membutuhkan waktu yang lama, maka dalam konsep ini istilah yang digunakan adalah sekejap mata. Namun dalam proses pengankatan ini orang-orang mati akan mendahului orang percaya yang masih hidup. Dan mereka yang masih hidup juga di ubahkan dengan "sekejap mata", karakteristik atau fisik yang dimiliki orang percaya sama seperti tubuh yang dimiliki Yesus Kristus setelah kebangkitan-Nya dari antara orang

\footnotetext{
${ }^{45}$ G.Raymond carlson Keselamatan (Malang, Gandum Mas, 1983). 8

${ }^{46}$ Dr. Jonathan Octavianus, Diktat Eskatologi (STTII, Surabaya). 25.

${ }^{47}$ Darmawan S. Bone Memerintah Sebagai Raja ( Kaltim STTT, 1998). 95
} 
mati. Sehingga tubuh ini dikatakan kudus dan layak untuk hidup di surga. Dan tubuh ini juga tidak bisa dibatasi oleh ruang dan waktu.

\section{Istilah Kebangkitan Pertama}

Memang dalam pembahasan Lukas 16:19-31, tidak membahas peristiwa kebangkitan karena dalam perumpamaan ini Yesus membahas tentang kondisi yang akan dialami oleh seorang yang kaya dan Lazarus yang miskin di alam setelah mati. Namun dalam konteks ini juga berbicara tentang peristiwa secara eskatologis. Dimana semua orang akan dihakimi baik yang sudah mati maupun yang masih hidup. Oleh kareana itu, ada kebangkitan bagi mereka yang sudah mati.Istilah "kebangkitan pertama" dijumpai dalam (Why 20:5-6), "Tetapi orang-orang mati yang lain tidak bangkit sebelum berakhir masa yang seribu tahun itu. Inilah kebangkitan pertama. Namun bila diteliti secara rinci kebangkitan itu lebih dari dua kali juga. Oleh karena itu, istilah kebangkitan pertama ialah bahwa kebangkitan itu adalah yang pertama bukan dalam pengertian nomor satu atau sebelumnya kebangkitan yang lain, tetapi dalam arti bahwa kebangkitan ini terjadi sebelum kebangkita akhir atau kebangkitan orang-orang fasik. ${ }^{48}$ Penegasan dari penjelasan diatas memberikan suatu pengertian bahwa pasti ada kebangkitan orang mati yang percaya kepada Yesus Kristus akan dibangkitkan terlebih dahulu, dalam kebangkitan pertama. Dimaknai dengan istilah kebangkitan pertama karena akan ada kebangkitan akhir (kebangkitan kedua).

\section{Waktu Kebangkitan Pertama}

Mengenai ketetapan waktu yang ditentukan untuk peristiwa kebangkitan Dr. Chris Marantika, dalam bukunya eskatologi menjelaskan urut-urutan peristiwa yang akan terjadi mengenai kebangkitan gereja ia menjelaskan bahwa kabangkitan pertama akan terjadi sebelum masa pengubahan tubuh bagi mereka yang percaya Yesus dan masih hidup dan sebelum masa kesengsaraan besar 7 tahun tribulasi. ${ }^{49}$ "Sebab pada waktu tanda diberi, yaitu pada waktu penghulu malaikat berseru dan sangkakala Allah berbunyi, maka Tuhan sendiri

${ }^{48}$ John F. Walvoord. Penggenapan Nubuatan Masa Kini- Zaman Akhir. (Yayasan Gandum Mas, Malang. 1996).424.

${ }^{49}$ Dr, Chris Marantika, ThD. Eskatologi

(Yogyakarta Iman Press, , 2004). 74 akan turun dari sorga dan mereka yang mati dalam Kristus akan lebih dahulu bangkit" (1 Tesalonika 4:16). Pengangkatan sebelum masa tribulasi ini adalah pandangan Pre-tribulasi didasarkan atas dasar kebenaran Alkitab, bukan asumsi rasional. Dr. Crhis Marantika, menguraikan konsep ini bahwa dalam Wahyu 3:10. Tuhan akan melindungi gerejaNya dari hari tersebut, I Tesalonika 1:10, 5:9; Wahyu 6:17, Tuhan Yesus akan menyelamatkan gereja-Nya dari murka yang akan datang itu, 1 Tesalonika 5:9, Allah tidak menetapkan kita untuk menerima murka, tetapi untuk beroleh keselamatan. ${ }^{50}$ Dasar inilah yang merupakan jawaban atas argumen-argumen rasionalisme seperti pandangan Mid- tribulasi. Bahwa pengangkatan di tengahtengah masa krisis. Pengangkatan sesudah krisis (pandangan Post-tibulasi).

\section{Kebangkitan Kedua}

Mengenai waktu kebangkitan kedua akan terjadi di akhir kerajaan Seribu Tahun, tetapi bukan untuk soal diselamatkan atau tidak, tetapi untuk penetapan ke dalam hukuman kekal, yaitu hidup dalam perpisahan dengan Allah untuk selamanya. Kematian ini adalah tingkatan dari kematian rohani yang berhubungan dengan kebejatan moral manusia karena menolak Yesus sebagai Tuhan dan Juruselamatnya secara pribadi.

\section{Tujuan Kebangkitan}

Dalam setiap peristiwa kebangkian pasti ada tujuan dari Allah karena yang mengijinkan kematian, dan memberi kehidupan serta membangkitkan orang mati hanya kemaha Kuasaan Tuhan. Tujuannya bangkitan adalah untuk diadali karena semua manusia harus mengahdapi taktah pengadilan Anak manusia. Namun pengadilan tidak bersama-sama, karena jika meneliti teks dalam Alkitab terdapat lima macam pengadilan. Kelimanya adalah pengadilan terhadap orang-orang percaya, penagdilan terhadap Israel, pengadilan terhadap bangsa-bangsa, pengadilan terhadap para malaikat yang jatuh, dan pengadilan Taktah Putih Besar... . Didalam 2 Korintus 5:10 dinyatakan bahwa orang percaya akan dibawa sesudah pengankatan gereja ke depan “ Kursi Pengadilan atau Bema Kristus."pengadilan ini hanya berlaku bagi orang percaya saja "Sebab kita semua harus menghadap takhta pengadilan Kristus, supaya setiap orang memperoleh apa yang patut diterima sesuai

\footnotetext{
${ }^{50}$ Ibid, 75.
} 
dengan yang dilakukan dalam hidupnya ini, baik ataupun jahat" (2 Kor 5:10). ${ }^{51}$ Prinsip pengadilan ini tidak berhubngan dengan keselamatan tetapi dinyatakan sebagai memberi pertanggungjawaban kepada Allah. Hal ini lebih jelas lagi dalam Roma $14: 12 \ldots$ setiap orang di antara kita akan memberi pertanggungjawaban tentang dirinya sendiri kepada Allah.

\section{KESIMPULAN}

Jadi kematian tidak peduli dengan kesedihanmu, karena kematian merupakan suatu kepastian yang harus dialami oleh manusia, kematian adalah jembatan untuk manusia bisa berpindah tempat dari fisik ke alam roh, kematian adalah bagian dari kehidupan dan dibalik kematian manusia ada kehidupan lain yang sedang menanti.

Setiap agama sangat konsisten dalam mengajarkan tentang kehidupan di balik kematian. Pengajaran tentang kondisi kehidupan setelah mati, selalu tersebar di seluruh dunia, supaya semua manusia memiliki harapan yang pasti tentang kehidupan di balik kematian, sesuai dengan keyakinannya masing-masing.

Harapan terbesar bagi manusia adalah hidup bahagia setelah mati, sukacita telah mananti di alam yang tak kelihatan yakni dunia orang mati. Namuan sampai saat ini masih banyak manusia yang takut mati, karena merasa kematian adalah hal yang merugikan. Padahal kematian adalah peristwa pasti yang datang secara tak terduga. Tetapi hal yang terpenting bukan masalah mati atau tidak mati, sebab kematian merupakan hal yang pasti tidak lagi membutuhkan persetujuan manusia.

\section{KEPUSTAKAAN}

[1] Anthony A. Hoekema, The Bible and the Future Grand Rapids: Eerdmans, 1979.

[2] Asali, Budi, M. Div. ReformendDogmatics.

Surabaya,Golgota Ministry, 2007.

[3] Archer, Gleason L, Encyclopedia of Bible

Difficulties. Malang Gandum Mas.2009.

[4] Bone, Darmawan S. Memerintah Sebagai Raja.

Kaltim STTT, 1998.

[5] Bone, Darmawan S. Memerintah Sebagai Raja. Kalimantan Timur STTT, 1998.

${ }^{51}$ Dr.Chris Marantika Masa Depan dunia Ditijau Dari Sudut Alkitab (ESKATOLOGI) ( Yogyakarta, Iman Press. 2007). 109
[6] Brow, Dr, Rebecca. He Came To Set The Captioves Free. Whitaker house Springdale .pensylvania, 1992.

[7] Boettner, Loraine, Immortality. Philadelphia: Presbyterian \& Reformed, 1967.

[8] Calvin Tracts and treatises of The Reformend faith,terjemah. H. Beveridge. Grand Rapids:

Eerdmand, 1958.

[9] Colson, Charles. PolaHidup Kristen. Surabaya Yakin 1989.

[10] Carlson, G.Raymond. Keselamatan. Malang, Gandum Mas, 1983.

[11] Dammananda, Sri, Kehidupan Tidak Pasti

Namun Kematian Itu Pasti. Jakarta: Yayasan

Dhamma Duta Carika, 1986.

[12] Erickson, Millard J, Teologi Kristen Volum tiga. Malang, Gandum Mas. 1985.

[13] Eugene, H.Marril, "Sheol" dalamDictionary of old testament. Wheaton: Victor Book, 1985.

[14] Famugia, Edward G, SJ. KamusTeologi.

Yogyakarta, FakultasTeologiWedabhakti

Yogyakarta. 1995.

[15] Farrugia, Edward G, KamusTeologi

.Yogyakarta, Kanisius, 1995.

[16] Hoekema, Anthony A. Alkitab dan Akhir

Zaman Surabaya, Momentum, 2014.

[17] Hwang, Thomas. Asal Usul Agama-Agama. AMI Publikasi, Korea 2013.

[18] Harris, Laird. SheoldalamTheological Wordbook of the Old Testament, Peny, R Laird Harris. Chocago: Moody Press, 1980.

[19]

Https://www.academia.edu/38215738/Seni_Tafsir_ Alkitab

[20] Intermediate State in the New Testament.

Holand: Franeker, 1966.

[21] Keene, Michael. Agama-Agama Dunia.

Kanisius IKAPI, Yogjakarta. 2006.

[22] Lockyer, Herbert, All ThePrabeles Of The

Bible. Grand Rapids: Zondervan, 1963.

[23] Ladd, George Eldon.

TeologiPerjanjianBaru.KalamHidup, Bandung 2012. [24] Marantika, Dr, Chris, ThD. Eskatologi.

Yogyakarta Iman Press, 2004.

[25] Marantika, Dr.Chris. Masa DepanduniaDitijau

Dari Sudut Alkitab (Eskatologi). Yogyakarta, Iman

Press.

[26] Merril, Eugene H. "Numbers"dalamThe Bible

Knowledge Commentary, Peny John F.

Walvoorddan Roy B Zuck. Wheaton: Victor

Book, 1985.

[27] Mahathera, Naradha, Intisari Agama Budha.

Semarang: Yayasan Darma Phala, 2002.

[28] Owens, John Joseph, Analytical Key to the Old

Testament. Grand Rapisd: Baker Book House, 1999. 
[29] Paker, J.I. Ensiklopedi Alkitab Masa Kini. Yayasan Komunikasi Bina Kasih, Jakarta 1974. [30] Pandensolang, Welly. Eskatologi Teologi Biblika. Yayasan Andi , Yogyakarta. 2004.

Ryrie, Charles C. Dispensationalism dari Zaman ke Zaman. Malang, Gandum Mas, 1995.

Soedarmo, R, Kamus Istilah Theologia. Jakarta, Bpk. GunungMulia 1984.

[31] Sproul, R.C. Kebenaran-Kebenaran Dasar Iman Kristen. Malang, Seminari Alkitab Asia Tenggara, 2002.

[32] Sandison, George \& Staff Bible answers for 1000 Difficul Questions. Malang Gandum Mas. 2006.

[33] Shibab, M. Quraish. Wawasan al-Qur'an 2013. [34] Tacoy, Selvester M. M.Div. Kamus Pintar Alkitab. Kalam Hidup Bandung, 2012.

[35] Travis, Stephen H. Christian Hope \& the Future. Downers Grove: InterVarsity, 1980.

[36] Tim LahayeLife In The Afterlife. Tyndale House Publisher Inc. Wheaton, 1980.

[37] Uisudhatara, Hidup dan Mati Sama Saja.

Klaten: Wisma Sambidhi, tt.

[38] Warren, Rick. The Purpose Driven Life.

Malang, Gamdum Mas 2006.

[39] Walvoord, Jhon F. PenggenapanNubuatan Masa Kini- Zaman Akhir.Yayasan Gandum Mas, Malang, 1996. 